\title{
The Demise and Rebirth of Literature - From Language to Multimedia: The Ecological Turn of Literary Media
}

\author{
Zhang Tong-de
}

\begin{abstract}
Bob Dylan, a brilliant US balladeer and lyricist, has been awarded the $\mathbf{2 0 1 6}$ Nobel Prize in Literature, sparking off a firestorm of controversy among literary and art circles. The main reason for this controversy lies in that literature and music are of distinct disciplines. This is what is called Bob Dylan's event in the world of letters. A reasonable interpretation of this literary event may be well illustrated by re-examining the conceptual history of literature-from documents, booklore to works of modern literary forms. As factual proof turns out, genres of Nobel laureates are not confined to belles-lettres (poetry, prose and drama) alone but miscellaneous ones. All the literary genres are nothing more than different kinds of literary representation of organized violence committed on ordinary speech. They incarnate the literariness in different ways by resorting to various media. In addition, a careful poetic analysis reveals that Dylan's song lyrics are brimming with poetic implications. As is manifested, literature as a form of high culture from 19th century onwards finds itself in its last throes while a new turn towards electronic \& digital media ecology of literature arises. The demise of literature essentially articulates a rebirth of new survival pattern of literature and manifests the evolutionary process of territorialization, de-territorialization and re-territorialization in literature.
\end{abstract}

Index Terms - Nobel prize in literature, conceptual history of literature, poetic expressions, media ecology.

\section{INTRODUCTION: MUSIC OR POETRY-A ROOT OF CONTROVERSY}

Bob Dylan's event, namely the event of 2016 Nobel Prize in Literature triggering off a very strong strain of controversy among literary scholars and critics, has put academicians under serious consideration: when we are heatedly debating about Dylan's event, what exactly are we arguing for? Is such event coincidental or does it signal the unavoidable development trend of literature in the future? Where does the dynamic boundary of literature extend to?

Critics have been scrambling for the justification in the awarding the Nobel Prize in Literature to Bob Dylan by establishing his identity as a poet rather than merely a lyricist, identifying commonality between song lyrics and poetry, or asserting that lyrics have the same literary merits as poetry

Manuscript received January 21, 2019; revised March 19, 2019. This work was supported in part by the Innovative Project of Cultivating International Talents for Postgraduates, GDUFS; and the 2017 Research Project of Talent Cultivation for Youth Innovation, 17QNCX02 (Center for Foreign Literature and Culture, GDUFS).

Zhang Tong-de is with the Center for Foreign Literature and Culture, GDUFS, Guangzhou, China 510420; Fuzhou Teachers' College, ECUT, Fuzhou, China 344000 (e-mail: zhang_tongde@ 163.com). does. Yet Dylan was not impressed, and he was so prudent and conservative that he did not knowingly confuse his song lyrics with literature, poetry in particular. Nevertheless, lines of flight in literature, or rather literary variations, have historically been shading into an irreversible trend. One of the highlights of literary creations lies in its inter-disciplinary nature and multimodal means. As the earliest ancient Greek literature, The Homer's Epic has survived from generation to generation in a combined form of singing and storytelling other than just being written in forms that reflect obvious mastery of literary mannerisms. Still, this monumental work deserves great literary merits not because of its circulation by word of mouth. Shi Jing, or The Book of Songs compiled by Confucius, a great educator in ancient China, is the earliest collection of poems in China which is composed of three sections: Feng (风 ballads), $Y a$ (雅 festival odes; court music) and Song (颂 sacrificial songs). Its wording is in the form of concise and refreshing rhymes, fitting to be sung by populace. Yet, it has exerted far-reaching influence upon the prosperity of Chinese poetry of later generations. The same is true to theatre arts. In his acceptance speech, Dylan's statement also set us thinking about the relationship between theatre arts and literature. He stated in his acceptance speech,

"His (William Shakespeare's) words were written for the stage. Meant to be spoken not read...when he was writing Hamlet...I would bet that the farthest thing from Shakespeare's mind was the question 'Is this literature?" [1]

Four hundred years later, Shakespeare's plays have bloomed into compelling masterpieces around the world. Such cases well prove that the definition or the boundary of literature is dynamic and inconclusive. Terry Eagleton, a British literary theorist and critic, points out,

"All literary works, in other words, are 'rewritten', if only unconsciously, by the societies which read them; indeed there is no reading of a work which is not also a 'rewriting'.... and this is one reason why what counts as literature is a notably unstable affair" (1983/2008:11). [2]

This account may illustrate profoundly the essential reasons why Dylan's event should touch off a heated debate among literary world.

In an era of consumer economy, high culture has taken a beating and is on the wane. Critics are inclined to announce at regular intervals the demise of literature in the traditional sense. Nevertheless, modem literati are still confined to the blinkered outlook that literature belongs to high culture and public intellectuals. And this is the point in which the significance of the 2016 Nobel Prize in Literature lies. It is not so much to broaden the definition of literature as to indicate the demise of contemporary literature and herald an 
ecological turn of literary media.

However, what calls for special attention is to have a better understanding of the phrase demise of literature: behind the superseding representation of various literary phenomena reflects an intrinsic logical evolvement and tension within literature itself, thrusting literature energetically from one style into another, and from one literary medium into another. To some extent, the fact that the latter one flourishes and prospers usually implies the former one expires and fades. In terms of literary evolution, the art form thrived in the latter stage usually gains deeper insight into the essence of literature than the previous one. What cannot be ignored is that the demise of literature actually means the withering away of the established boundary of literature on one hand and evolving into a redrawn boundary newly constructed by burgeoning literary media on the other hand. And the latter one is what may be called a rebirth of literature. By this token, it may be further articulated the evolutionary process of literature in terms of the specific concepts of territorialization, deterritorialization and reterritorialization by Gilles Deleuze and Felix Guattar. In this sense, the demise of literature just indicates a rebirth of new survival pattern of literature.

Furthermore, deeply affected by such factors as political ideology, economic development and cultural innovation, literature is constantly under transformation in different dimensions. Given all that, what is so called the demise of literature is nothing more than the end of a certain genre or style of literature at specified period in history. What is lost is some specific identity feature or role but its core properties remain continually in existence and respond to reality in a new and distinctive form. To put it in a different way, the demise of literature incarnates its self-reflexivity, which unceasingly gives impetus to literature propelling forward energetically. Similar to the word ends which has numerous connotations and summons an array of phenomena by Vincent B. Leitch in 2005, [3] the word demise appears multiple and complex, signifying not only the disappearance of old style of literature, but also the succession and transference into a new fashion.

Another dimension to declare the legitimacy of Dylan's prize is to get back on the track of literature itself. As to this, I would quote his words to illustrate it, 'We see only the surface of things. We can interpret what lies below any way we see fit' [4]. When we are discussing Bob Dylan's event, we are discussing about the boundary of literature, or specifically, the literariness that makes of literature. Yet it should be made clear that the media employed to construct literariness is rich and diverse. Do Bob Dylan's song lyrics entail literariness? And what have changed for the media by which literariness is to be constructed over the past decades? This demands a careful poetic analysis of his song lyrics.

\section{WHAT OF POETIC EXPRESSIONS?}

Bob Dylan earns the 2016 Nobel Prize in Literature for "having created new poetic expressions within the great American song tradition", but what of poetic expressions? Literary interpretation to Dylan's event demands careful consideration at this point. In the introduction part of the book The Lyrics: 1961-2012 by Bob Dylan, one of the editors of this book, Christopher Ricks, comments as follows:

"For fifty years, all the world has delighted in Bob Dylan's books of words and more than words: provocative, mysterious, touching, baffling, not-to-be-pinned-down, intriguing, and a reminder that genius is free to do as it chooses. And, again and again, these are not the words that he sings on the initially released albums". [5]

Ricks' comments have best summed up the striking characteristics of Bob Dylan's lyrics. They are elegant in verbal language and inundated with poetic expressions with great American song tradition.

\section{A. Elegance in Verbal Language}

The lyrics in Bob Dylan's albums flow easy and smooth without too much deliberate deviations from a certain norm, but just with resignation to the concrete situation and even with good will at times. Whatsoever the external melody may sound, the tensile force of language would never be underrated. Tuneful melody would never be achieved at the price of the loss of strong appeal arising from verbal recitation. Bob Dylan is skilled at spreading out the beauty of language to his melodic lyrics, hence retaining the poetic structure of his ballads when sung out, and the rhythm of its lyrics still flows clear and distinguishable when being read with silence, recited with a cadence or sung with zeal.

His lyrics actually have already laid a solid emotional foundation for the fluent operation of melody. In other words, Dylan's melody just renders the emotional tensions of what lyrics highlight, displaying the natural flow of emotions and feelings derived from our own experiences in our life world. His unique lyric creations have been so influential that he often became "the object of a steady stream of secondary literature". With his effusive, unrestrained melody and refined, poetic lyrics, Dylan united the worlds of music and literature in wedlock as no one else ever had. That's why Sara Danius, the permanent secretary of the Swedish Academy, said that while Dylan performs his poetry in the form of songs, that's no different from the ancient Greeks, whose works were often performed to music.

\section{B. Poetic Expressions within Great American Song Tradition}

Literature opens a window through which we may step on a journey towards a spiritual homeland of human civilization, so does music with strongly poetic lyrics. Bob Dylan desires wholeheartedly to take music as a means for truly expressing our living philosophy and life attitudes. Meanwhile, he is acutely aware of the cultural commensurability between poetry and lyrics writing, both addressing the concerns for the social reality in which we are living in and concerns for inner landscape where we reflect on ourselves, though by virtue of different discourses.

Engulfed by a flood of social vicissitudes in 1960s -'70s in America-Cold War, J. F. Kennedy's assassination, civil right movements, nuclear arms race, the Vietnam War, to name just a few, Dylan recorded social changes, aired his views and took a clear stand, and excited compassions within his audiences in lyrics combined with devoted musical performances. Specific historical moments, specific events, and specific genius to articulate grass-roots stance have 
created a valiant and heroic image of Bob Dylan fighting against injustices of every kind, prompting him to be "the voice of a generation". Yet, with the lapse of an era of too much social turmoil and too much weight on his mindset, Bob Dylan rejected his role as the most renowned protest singer and geared himself to take things into a larger, historical context. His concerns did not stay focused on individual events any more but on human progress, social development and self enhancement on the whole. A general survey of Bob Dylan's spiritual journey reveals that being a free soul is the eternal subject extolled in his lyrics brimming with literary conservation and cultivation. Bruce Springsteen, a US lead guitarist and musician, observed,

"Bob freed your mind the way Elvis freed your body. He showed us that just because music was innately physical did not mean that it was anti-intellectual. He had the vision and the talent to make a pop record that contained the whole world." [6]

That's why his songs would invariably capture a spirit of defiance, sagacity and humanistic concerns, thus "shoving against the boundaries of the definition of 'literature' just as he pushed past so many borders in music", as Carolyn Kellogg, a Los Angeles Times reviewer, remarked. Dylan is so adept at fusing music together with literature that his lyrics are not only rhymed gracefully but welled up ravishing ideas. His lyrics are imbued with vivacious perception of bloody life experiences and reflections on life, just a spontaneous overflow of poetic expressions of life, society and emotions, which constantly offers us a safe haven for an injured soul, encourages us to tide over difficulties and inspires us to forge ahead. The following excerpts from The Lyrics 1961-2012 (V): Slow Train Coming [7] may be good cases in point:

' $\mathrm{T}$ was in another lifetime, one of toil and blood

When blackness was a virtue and the road was full of mud I came in from the wilderness, a creature void of form

"Come in," she said, "I'll give you shelter from the storm" (Excerpt from "Shelter from the Storm", pp. 54)

Oh, sister, when I come to knock on your door

Don't turn away, you'll create sorrow

Time is an ocean but it ends at the shore

You may not see me tomorrow

(Excerpt from “Oh, Sister”, pp.99)

Granddad fought in a revolutionary war, father in the War of 1812

Uncle fought in Vietnam and then he fought a war all by himself

But whatever it was, it came out of the trees

Oh, that Leginnaire's disease

(Excerpt from “Legionnaire's Disease”, pp.197)

Themes may differ in Dylan's songs, yet his songs are suffused with much deeper feelings, some are more of sadness, some more of joy and some more of human-caring, all are different expressions of self-salvation in the final analysis.

\section{WHAT OF BEING NEW: ECOLOGICAL TURN OF LITERARY MEDIA}

A rational interpretation of Bob Dylan's literary event may be well illustrated by re-examining the conceptual history of literature-from documents, booklore to works of modern literary forms. As factual proof turns out, genres of Nobel laureates are not confined to belles-lettres (poetry, prose and drama) alone but miscellaneous ones.

\section{A. Brief Overview of the Conceptual History of Literature}

The concept of literature has undertaken a history of evolution process. It was not until in the 14th century that the word literature came into the English language. When written in lowercase letter, it refers to knowledge, learning, documents or all the writings by human beings. "Prior to 1800 literature and analogous terms in other European languages meant 'writings' or 'book knowledge'...as fine examples of the use of language and rhetoric...which included speeches, sermons, history and philosophy" (1997:21), [8] it was in the late 18th and early 19th century that the modern sense of literature as imaginative writing has been established, which is a product of disciplinary and cultural division in modern society. Thus, literature is defined in a much narrow sense and specifically refers to the arts of language, which includes such genres as poetry, prose, fiction and drama. As a matter of course, literary works are those artistic ones being imaginative, fictional and creative.

However, Russian Formalists hold a different viewpoint. They advocate that the essence of literature lies in its literariness, which is an act of "organized violence committed on ordinary speech", literature is thus being suspended to the level of linguistics research, leaving literary content, contexts and agents behind. Language alone becomes the medium by which literariness is to be constructed. Such views have been under bitter attack by scholars like Terry Eagleton, who maintains that literature could not be seen as an objective, descriptive category, nor could it be a subjective one. "...not only that literature does not exist in the sense that insects do, and that the value-judgments by which it is constituted are historically variable, but that these value-judgments themselves have a close relation to social ideologies" (1996:14). [9] By now, literature production mechanism has been taken into consideration under a historical and cultural context. With the advent of consumption age, one cannot help feel that the boundary of literature grows eroded and literary aesthetics has been generalized into the sphere of ordinary life. The once literariness as the essence of literature now yields to the quality of entertainment which is a state of activity, a mode of life experience and a certain feature stemming from an interaction between man and literary text. Immersed in the ambient of entertainment afforded by a multimedia of photos, caricatures, posters, instruments and acoustics, literature becomes the product of a positive balance within a cultural network, easily accessible and readers friendly.

In a word, it is a "Times They're a-Changing". In the era of modern telecommunications and digital image information, literature has been increasingly grown into one that quite distinct from the literary decency and solemnity readers once get accustomed to. What remains unchanged is that literature unremittingly solidifies its tradition of expressing human emotions, observing social life and exploring human nature, whatever form it may take. 


\section{B. Ecological Turn of Literary Media}

The present era sees the Internet technology and electronic media progress with each passing day, exerting great influence upon the way we communicate in every aspect. Under the background of globalization and post-modernism era, literature in the sense of modern stylistics ever since 19th century has come to an end in the current spatial-temporal architecture constructed by electronic-digital media. A new audiovisual culture era sets in. Bob Dylan's winning of the prize properly declares the demise of literature as a form of high culture. But how does it happen?

From the perspective of media ecology, human beings have negotiated through a history of oral culture and print culture, and into an era of electronically recorded information society. The literature which has enjoyed a populace of the Elites is a visual-oriented product of print culture whereas in the current context of electronic media, culture tends to be homogenous and stylized, and literature is prone to be pan-cultural. In this case, literature is not just a product of visual culture, but an organic texture integration of different perceived cultures that allow audiences to see, to hear, to taste, to smell and to touch. Accordingly, literature nowadays resumes new properties, which signals a re-tribalization of literature.

According to H. M. McLuhan, human society has undergone three social formations, namely, tribalization (oral culture), detribalization (print culture) and re-tribalization (electronic media culture). Oral traditions of culture have been superseded by print culture, which has promoted the overall level of literacy and facilitates the high-speed blossom of human civilization, but at the same time brought about visual and mechanical centralism. By contrast, in an electronic media context, almost all the sensory organs may be mobilized into artistic creation and we have embarked on a journey to re-tribalization, resulting in the rise of literature as a visual-audio art. "The medium is the message", because new media create new environments, whose contents contain those of the old environment. What's more, "it is the medium that shapes and controls the scale and form of human association and action" (1994:9), [10] this can be interpreted as follows: in the ecology of electronic-digital media, the scale to define literature is no longer being belletristic and the literariness of literature with the intervention of electronic media bears new traits - a perceptual quality of audio-visual cognition. By this token, it can be seen that the assessment principles adhered by the Swedish Academy are in line with requirements of contemporary literature.

Additionally, as advocates of media ecology stressed, with each occurrence of new media technology, the old medium is not being superseded but assimilated by a new one and became an integral part of it. The oral account has been substituted for the rise of printing press, making oral literature gain wide currency in the form of written scripts, expedite mass reading and yield a boom in popular literature. As can be seen, the medium content of oral account has been assimilated into that of printing medium. Similarly, when turning back to the Dylan's event, the poetic expressions in written script form as the old medium have been integrated into the content of Bob Dylan's sound world in the form of folk lyrics. That's the way we can grasp the Academy's awards, "for having created new poetic expressions within the great American song tradition".

\section{CONCLUSION}

To put it briefly, literature, once as an elite culture in the sense of stylistics, has undertaken an ecological turn in the new spatial-temporal context constructed by electronic-digital media, offering us a diversified cognitive means to perceive the multicultural world. Language, the oldest medium in literary works, has ceaselessly been standardized in a mass, industrialized society, hence losing its organic, vibrant vigor. Literary texts alone could not satisfy the need of self-referentially articulated desires without resorting to such mass media as broadcasts, TVs, films, music, face books, micro blogs, and other Internet platforms. Consequently, literature has to yield up its narrative traditions and embrace the symbolic revolution of literary conceptions at the ecological turn of literary media.

\section{REFERENCES}

[1] B. Dylan. Banquet Speech. [Online]. Available: https://www.nobelprize.org/nobel_prizes/literature/laureates/2016/dyl an-

[2] Te. Eagleton, Literary Theory: An Introduction (Anniversary Edition with A New Preface), Minnesota: University of Minnesota Press, 1983/2008.

[3] V. B. Leitch, "Theory ends," Profession, vol. 7, pp. 122-128, 2005.

[4] B. Dylan. Nobel Lecture. Available: https://www.nobelprize.org/nobel_prizes/literature/laureates/2016/dyl an-lecture.html

[5] Bob Dylan, The Lyrics: 1961-2012, Lisa Nemrow, Christopher Ricks, Julie Nemrow (eds.), London: Simon Schuster, 2014.

[6] Bruce Springsteen. Biography. [Online]. Available: https://www.imdb.com/name/nm0819803/bio

[7] B. Dylan, The Lyrics: 1961-2012 (V): Slow Train Coming (Chinese-English Edition), Guilin: Guangxi Normal University Press, 2017.

[8] J. Culler, Literary Theory: A Very Short Introduction, New York: Oxford University Press, 1997.

[9] T. Eagleton, Literary Theory: An Introduction, 2nd ed., Massachusetts: Blackwell Publishing, 1996.

[10] M. McLuhan, Understanding Media: The Extensions of Man Cambridge, Massachusetts/ London, England: MIT Press, 1994.

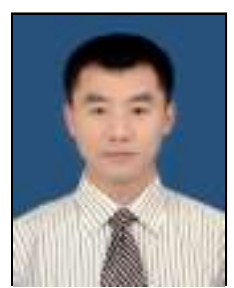

Zhang Tong-de was born in Weifang, Shandong Province, China on March $2^{\text {nd }}, 1978$. He obtained his master degree of Arts from Graduate School of Xi'an International Studies University in 2009 majoring in translation teaching then. In 2016, he was admitted to Guangdong University of Foreign Studies studying for a Ph.D. degree of comparative cultural studies.

He has been a college English teacher for about 10 years in East China University of Technology. The book Understanding Material Culture written by Ian Woodward published by Sage Publications in 2007 has been translated into Chinese by Zhang himself in November 2017 and it came off the press by Gansu Education Publishing House in April 2018. Also, the translation project of the book Poetic Conventions as Cognitive Fossils by Reuven Tsur is under way. Currently, his research interest focuses on cognitive poetics and comparative literature studies. 